УАK 347.243

ББК 67.407.1

DOI 10.22394/1682-2358-2017-2-117-122

T.V. Zhulich, post-graduate student of the Environmental and Land Law Department, Lomonosov Moscow State University (email: gutarina@mail.ru)

\section{STATE SUPERVISION} AS A WAY OF LEGAL MAINTENANCE

OF LAND PROPERTY USE ACCORDING TO THE ESTABLISHED RESTRICTIONS

Issues of state supervision over land use in accordance with the restrictions arising from the establishment of zones with special conditions for the use of territories are analyzed. The application of supervisory control measures in the field of supervision of the compliance with the regime of zones with special conditions, implemented without interaction with stakeholders is considered. Proposals on improving the current legislation are formulated.

Key words and word combinations: restrictions on rights to land plots, state supervision, planned (raid) inspections.
T.В. ЖКулич, аспирант кафедры экологического и земельного праВа Московского государственного университета имени М.В. Аомоносова (email: gutarina@mail.ru)

\section{ГОСУААРСТВЕННЫЙ НААЗОР КАК СПОСОБ ПРАВОВОГО ОБЕСПЕЧЕНИЯ ИСПОАЬЗОВАНИЯ ЗЕМЕ $\triangle$ НЫХ УЧАСТКОВ В СООТВЕТСТВИИ

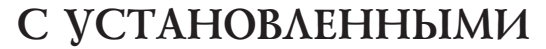 ОГРАНИЧЕНИЯМИ}

Аннотаџия. Анализируются проблемы государственного надзора за использованием земельных участков в соответствии с ограничениями, возникающими вследствие установления $30 н$ с особыми условиями использования территории. Рассматривается применение надзорно-контрольных мероприятий, осуществляемых без взаимодействия с заинтересованными лицами, в сфере надзора за соблюдением режима зон с особыми условиями территории. Сформулированы предложения по совершенствованию действующего законодательства.

Ключевые слова и словосочетания: ограничения прав на земельные участки, государственный надзор, плановые (рейдовые) осмотры.

$$
\Pi
$$

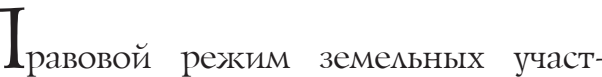
ков определяет содержание прав и обязанностей субъектов земемьных отношений, в том числе ограничения в использовании, устанав иваемые в связи с созданием зон с особыми условиями использования территории: охранных, санитарно-защитных, 
водоохранных, зон охраны объектов культурного наследия (памятников истории и культуры) народов Российской Федерации, зон затопления, подтопиения, зон санитарной охраны источников питьевого и хозяйственно-бытового водоснабжения, зон охраняемых объектов и т.А. Указанные ограничения как эмемент правового режима преАставцяют собой комплекс среАств правового воздействия в отношении субъекта прав на земельный участок, влекущих установление обязанности воздерживаться от определенных действий, связанных с использованием земельного участка, а ряд других совершать на основании специального разрешения. ОАним из способов правового обеспечения использования земельных участков в соответствии с установценными ограничениями явцяется государственный надзор.

НаАзорно-контрольная деятельность регулируется Федеральным законом от 26 декабря 2008 г. № 294-Ф3 «О защите прав юридических миџ и индивиАуальных предпринимателей при осуществлении государственного контроля (надзора) и муниџипацьного контроця» (Аалее - Закон № 294-Ф3) [1] . Он носит межотраслевой характер, устанавливая правовые основы проведения надзора и контроля за соблюдением законодательства при осуществлении размичных видов деятельности. Особенности проведения отдельных видов госуАарственного надзора определяются отраслевым законодательством.

Так, ст. 71-72 Земельного кодекса РФ [2] и Положение о государственном земельном надзоре, утвержденное постановцением Правительства РФ от 2 января 2015 г. № 1 [3], устанавцивают специальные правила осуществления федерального земельного надзора и муниципального земельного контроля. Примечательно, что соблюдение режима зон с особыми условиями использования территорий, включая использование земельных участков в соответствии с установленными ограничениями, охватывается предметом земельного

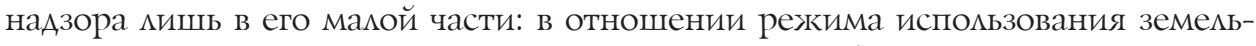
ных участков и месов в водоохранных зонах и прибрежных полосах водных объектов.

Надзор за соблюдением режима большинства зон с особыми условиями использования территорий осуществляется в рамках спеџиализированных виАов надзора: государственного экологического надзора, государственного санитарно-эпидемиологического надзора, федерацьного государственного контроля (надзора) в области рыболовства и сохранения водных биологических ресурсов, федерального государственного энергетического надзора, государственного транспортного надзора, государственного надзора в области охраны объектов культурного наследия и т.А.

Отнесение надзора за использованием земельных участков в соответствии с установленными ограничениями, определяемыми принадлежнностью земельного участка к зоне с особыми условиями использования территории, к специализированным видам надзора представцяется вполне обоснованным. ОАнако ограничения прав на земельные участки часто сформулированы общим образом. Так, в первой зоне округов санитарной и горно-санитарной охраны мечебно-оздоровительных местностей и курортов федерального значения запрещено осуществление всех видов хозяйственной Аеятельности, за исключением 
работ, связанных с исследованием и использованием природных ресурсов в мечебных и оздоровительных целях при условии применения экологически безопасных и рациональных технологий [4] . В охранной зоне объектов электросетевого хозяйства запрещается осуществлят мюбые Аействия, которые могут нарушить их безопасную работу, в том числе привести к повреждению или уничтожению, повлечь причинение вреда жизни, здоровью граждан и имуществу физических или юридических миџ, а также нанесение экологического ущерба и возникновение пожкаров [5]. В запретной зоне военного объекта не допускается проведение работ, создающих угрозу безопасности такого объекта и сохранности находящегося на нем имущества [6] . Аля того чтобы распознать правонарушения в этих областях, необходимы специальные знания в соответствующей отрасли.

Основная форма надзорно-контрольных мероприятий, по результатам которых возможно привлечение к ответственности, - плановые и внепцановые проверки (ч. 1 ст. 2 Закона № 294-Ф3), проводящиеся с обязательным участием юридических ииџ, индивидуаАьных предпринимателей, чья деятельность подлежит проверке. ОАнако охват подконтрольных субъектов такими проверками федеральных и региональных органов государственного надзора (контромя) низок. Ростехнадзором в 2013 г. проверено 7,3\%, в 2014 г. - 6,9\%, в 2015 г. - 36,4\% подконтрольных субъектов. Роспотребнадзором в 2013 г. проведена проверка 18,3\% подконтрольных субъектов, в 2014 г. - 17,3\%, в 2015 г. - 17,9\%. Росприроднадзором в 2013 г. проверено 15,7\% подконтрольных субъектов, в 2014 г. - 16,2\%, в 2015 г. - 13,2\%. Роскомнадзор в 2013 г. осуществил проверку 1,3\% подконтрольных субъектов, в 2014 г. - 0,4\%, в 2015 г. - 0,8\% [7]. В связи с этим представляется целесообразным предусмотренное планом мероприятий («дорожной картой») по совершенствованию контрольно-надзорной деятельности в Российской Федерации на 2016-2017 гг. [8] расширение использования форм надзора, не требующих непосреАственного взаимодействия межАу проверяющими и проверяемыми.

Согласно ст. 13.2 Закона № 294-Ф3 надзорно-контрольные мероприятия, осуществляемые без взаимодействия с заинтересованным мицом в целях сбора информации, проводятся в рамках плановых (рейдовых) осмотров, обслеАований. Статьей 8.3 Закона № 294-Ф3 (в редакции, действующей с 1 января 2017 г.) расширен перечень надзорно-контрольных мероприятий, осуществмяемых без взаимодействия с заинтересованными миџами [1]: к ним отнесены исследование и измерение параметров природных объектов окружающей среды (атмосферного воздуха, вод, почвы, недр) при осуществлении государственного экологического, социально-гигиенического мониторинга; измерение параметров функщионирования сетей и объектов электроэнергетики, газоснабжения, водоснабжкения и водоотведения, сетей и средств связи, включая параметры излучения радиоэлектронных средств и высокочастотных устройств гражданского назначения; наблюдение за выполнением обязательных требований посредством анализа информации о деятельности мибо Аействиях юридического мица и индивидуального предприниматеця, обязанность по представцению которой возцожена на такие кица в соответствии с федеральным законом. 
Актуальность применения указанных форм надзора обусловлена тем, что вреА, причиняемый в результате нарушения режима зон с особыми условиями использования территорий, может проявиться Аишь по прошествии времени, и это затрудняет возможность назначения внеплановой проверки. Примером нарушения, последствия которого были неочевидны, пока не приобрели глобальный характер, служит описанная О.А. Самончик распашка земель в водоохранных зонах, повлекшая масштабное заиление русел рек [9, с. 21] . Неочевидность угрозы не свидетельствует о том, что в соблюдении ограничений прав на земельные участки и эффективном надзоре за этим отсутствует необходимость.

Цемь плановых (рейдовых) осмотров, обследований - выявление нарушений обязательных требований, принятие мер их по пресечению, а также сбор информации о них Аля принятия решения о назначении внеплановой проверки. Пкановые (рейдовые) осмотры проводятся уполномоченными органами в оАностороннем порядке.

Анализ нормативных правовых актов, регулирующих порядок проведения плановых (рейдовых) осмотров, обследований дмя выявления признаков нарушений законодательства России, связанных с использованием земель / земельных участков [10], свидетельствует, что в задачи таких осмотров не входит выявление нарушений требований законодательства при использовании земельных участков в соответствии с установленными ограничениями. Кроме того, Аействуюшее законодательство не включает в перечень объектов, подлежащих плановым (рейдовым) осмотрам, зоны с особыми условиями использования территории, и, как следствие, не предусматривает спеџиальный порядок их проведения в отношении соблюдения режима использования зон с особыми условиями территории, в том числе земельных участков, частей земельных участков, расположенных в границах таких зон. В отсутствие специального правового регулирования суды расценивают проведение осмотров зон с особыми условиями использования территории как незаконное [11].

Представляется целесообразным включить в число объектов надзора, провоАимого без взаимодействия с заинтересованными миџами, зоны с особыми усмовиями использования территории, а также внести изменения, отражающие особенности осуществления данных мероприятий, в нормативные правовые акты, регулирующие отдельные виды надзора. В частности, следует установить перечень мероприятий по надзору без взаимодействия с заинтересованными миџами, подмежащих проведению в соответствующей зоне с особыми условиями использования территории; перечень нарушений, которые могут выявцяться при осуществлении данных мероприятий; особенности порядка их проведения; источники финансирования (Аля осушествления замеров параметров окружающей среды, параметров функщионирования сетей).

Необходимо также устранить следуюшую комлизию: с одной стороны, согласно п. 2 ст. 13.2 Закона № 294-Ф3 информация, собранная в ходе плановых (рейдовых) осмотров, обследований, может использоваться мишь Аля обоснования необходимости назначения внеплановой проверки; с Аругой стороны, в силу п. 1 ч. 1 ст. 28.1 Кодекса Российской Федеращии об административных 
правонарушениях [12] непосредственное обнаружение Аолжностными мицами, уполномоченными составцять протоколы об административных правонарушениях, Аостаточных данных, указывающих на наличие события административного правонарушения, является основанием Аля возбуждения дела об административном правонарушении. ЕАинообразная судебная практика по вопросу соотношения этих норм не сложилась. В одних случаях суды исходят из Аопустимости привлечения к административной ответственности при обнаружении правонарушения в ходе осушествления надзорно-контрольных мероприятий, не требующих взаимодействия с проверяемым, без проведения внеплановой проверки, в других - полагают необходимым ее назначение $[13 ; 14]$.

Принимая во внимание насущную потребность в мерах оперативного реагирования на обнаруженные нарушения действующего законодательства, предложено компромиссное решение. С 1 января 2017 г. органы надзора и контроця наделены правом по результатам анализа информации, полученной без взаимодействия с заинтересованным миџом, объявлять ему предостережение о недопустимости нарушения обязательных требований, в том чисме установленных муниципальными правовыми актами, предмагать принять меры по обеспечению их соблюдения и уведомить об этом уполномоченный орган в установленный в предостережении срок. Аанные изменения следует оџенить как положительные, но недостаточные, поскольку законодательство не определяет правовые последствия игнорирования правонарушителем полученного преАостережения. В такой правовой конструкции предостережение носит фактически рекомендательный характер. Представцяется необходимым придать предостережению юридическое значение. Во-первых, следует сделать нереагирование на предостережение основанием дяя возбуждения дела об административном правонарушении без необходимости назначения внеплановой проверки. В некоторых случаях может назначаться административное расследование. Во-вторых, требуется предусмотреть существенное увеличение санкции за правонарушение в случае, если ранее правонарушителю было объявлено предупреждение, которое он оставиц без соответствующей реакции.

Таким образом, Аля значительного повышения эффективности надзора за использованием земельных участков в соответствии с установценными ограничениями, определяемыми его принадлежностью к зоне с особыми условиями использования территории, необходимо следующее:

- внести изменения в Закон № 294-ФЗ, предусматривающие включение зон с особыми условиями использования территории в число объектов плановых (рейдовых) осмотров, а также иных мероприятий по надзору без взаимодействия с заинтересованными мицами;

- внести изменения в нормативные правовые акты, регулирующие осуществление надзора в соответствующей сфере, в части определения особенностей проведения мероприятий по надзору без взаимодействия с заинтересованными мицами в зонах с особыми условиями использования территории;

- внести изменения в Закон № 294-ФЗ и КоАП РФ, предусматривающие правовые последствия нереагирования правонарушителем на объявление преАостережения органом государственного надзора. 


\section{Библиографический список}

1. О защите прав юридических лиц и индивидуальных предпринимателей при осуществлении государственного контроля (надзора) и муниципального контроля: Федер. закон от 26 дек. 2008 г. № 294-Ф3. URL: http://www.consultant.ru/document/cons_doc_LAW_83079/

2. Земельный кодекс Российской Федерации от 25 окт. 2001 г. № 136-Ф3. URL: http://www. consultant.ru/document/cons_doc_LAW_33773/

3. Об утверждении Положения о государственном земельном надзоре: постановление Правительства РФ от 2 янв. 2015 г. № 1. URL: http://www.consultant.ru/document/cons_doc_LAW_ $173212 /$

4. Об утверждении Положения об округах санитарной и горно-санитарной охраны лечебно-оздоровительных местностей и курортов федерального значения: постановление Правительства РФ от 7 дек. 1996 г. № 1425. URL: http://base.garant.ru/2133062/

5. О порядке установления охранных зон объектов электросетевого хозяйства и особых условий использования земельных участков, расположенных в границах таких зон: постановление Правительства РФ от 24 февр. 2009 г. № 160. URL: http://base.garant.ru/12165555/

6. Об установлении запретных и иных зон с особыми условиями использования земель для обеспечения функционирования военных объектов Вооруженных Сил Российской Федерации, других войск, воинских формирований и органов, выполняющих задачи в области обороны страны: постановление Правительства РФ от 5 мая 2014 г. № 405. URL: http://base. garant.ru/70649860/

7. Доклад об осуществлении государственного контроля (надзора), муниципального контроля в соответствующих сферах деятельности и об эффективности такого контроля (надзора) в 2015 году. URL: http://economy.gov.ru/minec/about/structure/depgosregulirineconomy/201606070

8. Об утверждении плана мероприятий («дорожной карты») по совершенствованию контрольно-надзорной деятельности в Российской Федерации на 2016-2017 годы: распоряжение Правительства РФ от 1 апр. 2016 г. № 559-p. URL: http://docs.cntd.ru/document/420346602

9. Самончик O.A. Ограничения права землепользования сельскохозяйственных предприятий / отв. ред. Н.И. Краснов. М., 1989.

10. Об утверждении Порядка оформления и содержания плановых (рейдовых) заданий на проведение плановых (рейдовых) осмотров, обследований и оформления результатов таких плановых (рейдовых) осмотров, обследований: Приказ Минсельхоза РФ от 16 окт. 2015 г. № 475. URL: http://docs.cntd.ru/document/420311863

11. Постановление Арбитражного суда Волго-Вятского округа от 16 авг. 2016 г. по делу № А29-10785/2015; решение Арбитражного суда Республики Северная Осетия - Алания от 12 авг. 2016 г. по делу № А61-1567/2016; решение Арбитражного суда города Севастополь от 19 авг. 2016 г. по делу № A84-1605/2016. URL: http://kad.arbitr.ru.

12. Кодекс Российской Федерации об административных правонарушениях от 30 дек. 2001 г. № 195-Ф3. URL: http://www.consultant.ru/document/cons_doc_LAW_34661/

13. Постановление Восьмого арбитражного апелляционного суда от 20 июля 2016 г. по делу № A75-3949/2016; постановление Тринадцатого арбитражного апелляционного суда от 16 нояб. 2016 г. по делу № A26-4690/2016; решение Арбитражного суда Республики Карелия от 5 июля 2016 г. по делу № A26-4688/2016. URL: http://kad.arbitr.ru.

14. Решение Арбитражного суда Камчатского края от 6 июля 2016 г. по делу № А241222/2016; решение Арбитражного суда Республики Северная Осетия-Алания от 12 авг. 2016 г. по делу № A61-1567/2016. URL: http://kad.arbitr.ru. 